\title{
Response
}

\section{Fernando Henrique Cardoso}

The articles published in this issue commemorating the 40th anniversary of Dependency and Development in Latin America are very generous about the influence that the book has had within the specialized literature. I am grateful for this and for the comments and criticisms on the book and the essay "New Paths." I would also like to briefly clarify some of the many points raised.

While not limited to a specific conjuncture, Dependency and Development did refer to a period in the economic and social life of Latin America and to a specific moment in the debate about the developmental chances of countries on the periphery of the capitalist system. At the time, we were conditioned by the bipolarity and the struggle between two socio-economic systems characteristic of the Cold War. Simultaneously, the conditions for moving from a situation of underdevelopment to one of development were under intellectual debate. In the tradition of the founders of the social sciences in the nineteenth century, as observed by Patrick Heller, Dietrich Rueschemeyer, and Richard Snyder, we were proposing a broad interpretation of historical circumstances, stressing the structural constraints on human action to transform given situations as well as the possibility, variability, and effectiveness of such.

We did this without resorting to the kind of wishful thinking that explains events exclusively in terms of the leaders' decisions and also without believing that structural constraints limit choices. These are not actual individual choices. They are alternatives that arise in concrete situations, which may or may not be accepted and

Fernando Henrique Cardoso was President of Brazil (1995-2003).

F. H. Cardoso $(\bowtie)$

Instituto Fernando Henrique Cardoso, Rua Formosa, 367, $6^{\circ}$ andar, Centro, São Paulo, SP 01049-000, Brazil

e-mail: ifhc@ifhc.org.br 
put into practice by the social agents. It was not, and is not, the case of analyzing indeterminate political choices, as Gerardo Munck's article argues, and even less a question of evaluating the relationship between them and the performances of governments or societies. Performance, especially in economic terms, depends on local and global conjunctures.

The cycle of accelerated international economic growth from 2003 to 2007 benefited practically all the developing economies, especially the so-called "emerging" ones, in particular the BRICs, irrespective of their historical form of insertion in the world economy. Similarly, recent advances in the reduction of social inequality, poverty, and extreme poverty have been significant; nevertheless, these problems continue to be enormous. This reduction came about as a result of the new social policies put into practice, particularly in the area of land reform, cash transfer policies, and the increase in the minimum wage in real terms. These achievements have been accompanied by advances in education and health policies. With the accelerated growth of the economy, there was an expansion in employment and income, rendering the results of the social policies more effective.

Although these kinds of policies are more noticeable in countries whose governments are "social democratic" and which encourage economic integration with the global market, they are becoming more widespread. Such policies are also gaining sway in countries whose governments are considered to be against globalization. The difficult years that will follow the current financial crisis will probably see a reduction in the outcomes of social policies adopted by governments both in favor of and against global economic integration. In this respect, the warnings issued by Erik Wibbels are timely, as is his observation about the lack of rigor in the various definitions of dependence in Dependency and Development. However, because the works on dependence were aimed more at interpreting historical situations than at measuring the effect of analytical variables, the lack of precision did not prevent the perception of the variety of forms of dependence from illuminating the analysis of some historical processes. And this continues to be the case, as shown in the article by László Bruszt and Béla Greskovits on the Eastern European countries and by Atul Kohli's article on Asia.

It also makes little difference that the above-mentioned authors chose different angles from those in Dependency and Development to highlight historical-structural processes that affect socio-economic development such as, for example, the degree of effectiveness of state apparatuses. When, however, for reasons of intellectual or methodological interest, one attempts to measure the effects of "dependence" or of the types of dependence on so many other variables, analytical rigor requires precise definitions. The approach used by myself and Enzo Faletto was not intended to propose a framework for building a "theory of dependence." In fact, we were skeptical about such a possibility, believing that if there were a theory about situations of dependence, it should be that of capitalist development, encompassing the Center and the Periphery. More modestly, we were referring to "situations of dependence," the theoretical explanation for which would be contained in broader frameworks into which we did not venture.

In Dependency and Development, we distinguished some historical modes of insertion of the peripheral economies into the global system. What we proposed was not a dichotomy but a triangle whose sides were formed by two types of insertion: 
that of enclave economies and that of economies driven by the local accumulation of capital on the part of domestic producers. The base of the triangle, which not all countries would be a part of, would be formed by the industrialization driven by both domestic and multinational economic forces. We were engaged in a dialog with the two main types of interpretation current at the time: one which limited the internal dynamism of the peripheral countries to external factors, that is, to imperialism. For this type of interpretation, socio-economic development would depend on domestic forces bringing about a socialist revolution. The other perspective, by contrast, put almost exclusive emphasis on the internal dynamism of each country, refusing to recognize effects resulting from foreign capital.

The mechanical distinction between internal and external factors did not help in understanding situations of dependence. Whether we liked it or not, the insertion of some of the region's economies into the market was driving industrialization and economic growth. Along the same lines, years later, referring specifically to Brazil, I developed the notion of "associated-dependent development" as a type of development stemming from the previous forms of dependence (Cardoso 1973).

Although the interpretation we proposed employed a historical-structural methodology, in the book we used a more Weberian typology: from some countries, we selected certain features to highlight the argument about the historical variability of the forms of insertion of peripheral economies into global capitalism and the different types of social organization and political alliances they sought. In truth, although we alluded to countries at determined junctures, there was an abstract theoretical presupposition behind our scheme: the form adopted by the "capital circuit." Imprecisely, we referred to one of the forms of dependence as characterized by national control over the productive sector. In reality, the distinction was different. It was between countries whose investment had originated predominantly through domestic savings and those that had received foreign investment. When investment resulted from capital accumulated domestically, the product circulated in the international market, where the profit was realized, and then returned to be reinvested or spent in the domestic market, thus driving its expansion.

We made use of this scheme, taking the Marxist analysis of merchandise as a reference, in which we have $\mathrm{C}-\mathrm{M}-\mathrm{C}$, where " $\mathrm{C}-\mathrm{M}$ " is the transformation of commodities into money, and " $\mathrm{M}-\mathrm{C}$," in turn, is the transformation of the money into another, different commodity with an equal or higher value, presumably thanks to the circulation of the merchandise. For Marx, this circuit obscures the surplus value of the production process, which would be obtained on the labor power side (surplus labor) and not on the trade side.

In the enclave economies, the capital originates abroad. It is invested in the domestic market, and the profits are realized by means of the circulation of the production in the international market, which retains a part of what is added as profit and returns only a part of the amount necessary to maintain or expand the enclave. By contrast, in the form of dependence based on domestic accumulation, the profits obtained from the circulation of merchandise return to their point of origin, enabling greater expansion of production thanks to new investments and the growth of the domestic market. Thus, the development of more complex social relations is enabled, that is, the formation of a broader working class, a more diversified business base, and the eventual formation of middle classes, whereas the form of 
accumulation and circulation of products in the enclaves limits these expansion processes. When they occur, it is due to political pressure-from the middle class and bureaucratic bodies, such as the Army-over the state to extract taxes and enhance local consumption and/or investment. In certain circumstances, these pressures lead to the nationalization of the enclaves.

Jonathan Conning and James Robinson are right in observing that, in Bolivia, Simón Patiño and the other mining magnates were not foreigners and that in Venezuela before the petroleum boom or in some Central American countries before the fruit-growing enclaves gained control of local production, one could not talk about enclaves. However, we were less interested in the nationality of the producers than in the form of insertion in the international market and its effects on the circulation of capital and on social relations. Similarly, in cases of "associateddependent development," despite the weight of the multinational corporations, the nationality of the producers and owners is less important than knowing whether the domestic market plays a role in the capital circuit and, in the case of global exporting companies (domestic or foreign), whether there is a surplus that may be used to spur diversification of domestic production. Furthermore, given the diversity of the domestic economy, more diversified elites may emerge as may more complex political relations among classes and between classes and the State. Thus, this type of country may achieve greater autonomy in decision-making, enabling national interests be taken into account. But I do recognize the ambiguity present in our text.

In Dependency and Development we did not make any predictions about which of the forms of dependence would have a greater chance of ensuring economic growth, improving income distribution or guaranteeing democracy. At the time, one of the political options, socialism, emphasized its successes in terms of equality; it showed some advantages with regard to economic growth but paid little attention to democracy. The democratic theme in Latin American social sciences emerged strongly in the 1970s, coming to dominate the scene after the fall of the Berlin Wall but not before that. Because of the variability of the conjunctures, countries whose economies were originally enclaves, or where enclaves were predominant at some moment, were transformed. In some cases, this process led to new types of linkages with the international market, blurring the differences among countries, as the article by Conning and Robinson shows so well.

Today, the situation is quite different. The fading away of the socialist alternatives, of real socialism, the transformation of China into a state-capitalist economy run in association with multinational companies under the political control of a large Communist Party, the growth of the emerging economies, the unification of Europe, the relative decline of the American economy, and underlying all this, the technological revolution in communication and transportation strengthening productive and commercial ties on a global scale have changed the scene in comparison with the 1960s. The speculations in "New Paths" about new routes in Latin America and in the world are a response to these transformations. In spite of the aforementioned changes and many others, socio-economic inequality among nations persists and continues to be relevant for broader explanations. Are there alternatives for economic development and greater autonomy in decision-making given the existing inequalities? May some countries characterized as dependent shift from the periphery to the center? In addition to China-which underwent a socialist 
revolution, thus changing its classification-could countries like Brazil, India, Mexico, and so many others follow such a course?

History is an open horizon. But for such a transformation, which would change the international division of labor and production, to occur, certain conditions are lacking. The modern economy is based on invention, and there are so-called "knowledge societies." This explains the strength of the more developed countries: they have the scientific and technological conditions to innovate and retain the lead in production. Furthermore, capital flows continue to be very centralized. For this reason, the basic questions for analyzing the current situation of the emerging countries are precisely those posed by Peter Evans in his illuminating article. And they have immediate political implications: if the emerging countries (basically the G-20 countries minus the G-7 countries) are capable of exercising enough influence to shift institutions and modify the practices that dominate the global scene, for example, in trade, patents, and financial regulation, they will be in a position to prepare their shift from the periphery to the center. And this is not merely an economic question, it is a political one.

Comparing my writings from the 1960s with those of today, it is not so much a question of a shift in my perspective, as Peter Evans suggests, because the reality has changed, and in the social sciences, interpretations respond to historical changes. What was previously improbable, agency on a global scale by actors in the South, is a possibility today. I do not therefore think that international conditions-including the social forms of capitalism and the market - are an immutable "datum." At this juncture, it would appear more feasible to fight for control of certain rules of the game to the benefit of the emerging countries than to change the game altogether. It is true that I currently see more opportunities for improving the situation of the less favored social strata in the poorer countries, but this does not imply that capitalism or the market will solve the problem of poverty nor that there is no need to seek better solutions. Still, social pressure together with governmental capacity to influence the market, respecting the basic rules of the game, plus effective social policies can improve living conditions for needy populations and the quality of life in general. I emphasize the participation of civil society in government decisions and in the enhancement of social policies under a democratic environment as a safeguard to compensate for the capitalist trend toward wealth concentration and inequality.

Both on the domestic and international scenes, the situations faced by societal actors constitute at the same time "a datum" and a challenge. For this reason, in "New Paths," I mentioned the alternatives that are emerging in Latin America. I did not perform a systematic political analysis; I merely highlighted the paths being followed by some countries in the region. I attribute particular value to one such path: economic integration with the global market combined with relative national autonomy in decision-making, a more competent State that is capable of implementing active social policies, and a framework of democratic rules promoting partnerships between government and civil society. I call this "globalized social democracy." But there are various paths to development. It is not possible to propose a recipe. The paths will be conditioned by the history of each country, by its material base, and by the actions of its leaders and people.

Social democracy in the countries which are not completely developed may expand with globalization because it provides economic growth and modernized 
production. For anachronistic factions of the left, the only alternative to underdevelopment is centralized state control of the economy. There are indeed alternative paths. Moreover, one cannot think of Latin American social democracy in the same mold as the European welfare state. European social democracy has always been associated with union pressure, labor parties, and progressive taxation within a democratic state. These factors ensured better living conditions for the poor and even the middle classes. In Latin America, however, the fight against poverty and misery, given the lack of social cohesion and political power from below, requires more action from governments in conjunction with broader segments of civil society, such as business, churches, "public opinion," and NGOs. Unions representing workers from private and public sectors of the economy tend to guard their privileges zealously. The class alliances necessary to reduce poverty and enhance the wellbeing of people are thus different from what occurred in Europe, where the pact between employers and employees, buoyed up by a prosperous economic situation, engendered European social democracy.

I did not want to coin a "concept" with the expression "globalized social democracy." I only wished to say that some countries whose economies were opened to the outside world were able to reduce poverty despite the basic inequality inherent to the entire capitalist system. But I did not include all the countries whose governments are favorable to integration with the global market as cases of "globalized social democracy." I restricted the characterization to Brazil, Chile, Mexico, and Uruguay, although it would be possible to add Costa Rica and maybe even the Dominican Republic ${ }^{1}$ because in these countries societal pressure on the State led to social policies that produced positive effects. Whether the economies of some of these countries in the past were enclaves is not important because today they are not. Since I do not draw a mechanical link between historical structures, the political paths followed, and the way the structural forms were modified, I see no significant conceptual problem in this procedure.

Reading the criticisms of what I wrote in "New Paths" about countries with governments considered to be populist adopting an antiglobalization rhetoric may give the impression that I regard such governments as incapable of reducing the prevailing levels of poverty, which is not correct. Munck demonstrates that certain countries, such as Venezuela, may have reduced poverty more rapidly than others whose integration with the international market is growing. I do not deny that such processes may occur. As the state becomes the main producer and supplier of goods and services, poverty may be reduced more rapidly. If, as in Cuba, a socialist system prevails, the capitalist pattern of income concentration is substituted by greater equality, a process that is not occurring in Venezuela. Still, the contrast with the alternative historical path, "globalized social democracy," is striking: that option provides an impetus for economic growth and diversification, strengthens individual guarantees, stimulates the formation of democratic institutions, and at the same time, reduces poverty and misery.

\footnotetext{
${ }^{1}$ I was not familiar with Sandbrook, Edelman, Heller, and Teichman's book, Social Democracy in the Global Periphery, when I wrote "New Paths." Had I been, I would have extended the range of my suggestions.
} 
Poverty reduction may result from a conjunction between populist leaders aiming to please the masses and a favorable economic situation. As soon as one or both conditions disappear, social progress is at risk. By contrast, the institutional and structural changes promoted by the social democracies tend to be longer lasting because they stem from societal pressure for the creation of institutions capable of assuring continuity. The comparison between the two paths of social progress - one rooted in social democratic practices and the other in a more populist-clientelistic approach - cannot be restricted to a question of the quantity of outputs generated by social policies. The quality of the means used to achieve these results also matters. In "New Paths," I tried to draw attention to these differences, without denying the positive achievements that could occur in political systems where state intervention and charismatic leadership are the main drivers of policies.

\section{References}

Cardoso FH. "Associated-dependent development: theoretical and practical implications". In: Stepan A, editor. Authoritarian Brazil: Origins, policies, and future. New Haven: Yale University Press; 1973. p. $142-78$.

Fernando Henrique Cardoso former President of Brazil (1995-2003) for two consecutive terms, is currently president of the Instituto Fernando Henrique Cardoso (Sao Paulo, Brazil) and honorary president of the Party of the Brazilian Social Democracy (PSDB). He is a member of the board of directors of the Club of Madrid (Madrid, Spain) and of the board of directors of the Inter-American Dialogue (Washington D.C.). He is also a member of the Clinton Global Initiative (New York), of the World Resources Institute (Washington D.C.), of the Thomas J. Watson Jr. Institute for International Studies of Brown University (Providence) and of the United Nations Foundation (New York). 